\title{
OBECNOŚĆ MISJI ORAZ WIZJI PRZEDSIĘBIORSTWA NA STRONACH WWW WYBRANYCH FIRM Z RANKINGU DIAMENTY FORBES 2017
}

Z a ry s tr e ś c i: Wizja oraz misja firmy stanowią wyróżnik wobec konkurencji, którego nie da się łatwo kopiować. Utrzymywanie wysokiego stopnia konkurencyjności we współczesnym świecie wymaga, oprócz dobrych strategii biznesowych, nieustannej innowacyjności oraz elastyczności, także oparcia wszelkich działań i procesów o twardy kręgosłup wartości, który niejako stanowi konstytucję przedsiębiorstwa. Celem artykułu jest przegląd stron www wybranych za pomocą próby reprezentatywnej przedsiębiorstw z listy Diamenty Forbes 2017 i stwierdzenie czy na w/w znajduje się opis misji lub/oraz wizji przedsiębiorstwa.

S ło w a k l u z o w e: misja, wizja, Forbes, przedsiębiorstwo

K 1 a s y fik a c j a E L: L 19; M31

\section{WSTĘP}

Współczesna sfera ekonomiczno-gospodarcza jest wytworem postępujących po sobie rewolucji przemysłowych, a następnie rewolucji naukowo-technicznych. Zmiany strategiczne mające korzenie w tych właśnie rewolucjach doprowadziły do ukształtowania się bardziej zautomatyzowanych urządzeń i modeli biznesowych, które umożliwiają zdalne sterowania nie tylko wytwarzaniem rozmaitych produktów, ale też świadczeniem przeróżnych usług oraz dają możliwość szybkiego duplikowania i produkcji różnego rodzaju dóbr. Ów stan rzeczy implikuje wysoką konkurencyjność firm działających na rynku i daje możliwości szybkiego nadrabiania zaległości wobec konkurencji,

\footnotetext{
*Adres do korespondencji: Sławomir Króliczek, Górnośląska Wyższa Szkoła Handlowa im. Wojciecha Korfantego, ul. Fabryczna 3, 34-120 Andrychów, e-mail: skroliczek@gmail.com;
} 
niemalże w każdej dziedzinie. Nie jest więc przypadkiem, że wizja oraz misja firmy często stanowią wyróżnik wobec konkurencji, którego nie da się łatwo kopiować. Utrzymywanie wysokiego stopnia konkurencyjności we współczesnym świecie wymaga, oprócz dobrych strategii biznesowych, nieustannej innowacyjności oraz elastyczności, także oparcia wszelkich działań i procesów o twardy kręgosłup wartości, który niejako stanowi konstytucję przedsiębiorstwa. Można zaryzykować stwierdzenie, że każda firma posiada formalną lub nieformalną konstytucję. Logiczne również wydaje się. że podążanie w kierunku rozwoju zapisanym w misji daje organizacji dodatkową korzyść w postaci realizacji danego słowa za pomocą czynu [Jagielski, 2014, s. 100]. W przypadku wielkich międzynarodowych korporacji jest to często zbiór dokumentów o charakterze strategicznym, natomiast w sytuacji mniejszych podmiotów często mamy do czynienia z bardzo nieformalnym dokumentem lub jego brakiem. Wobec powyższego warto zadać sobie pytanie czy to właśnie owa misja i wizja twórców Apple czy Googla była decydującym czynnikiem sukcesu tych firm? Odpowiedź na to pytanie wydaje się być na tyle obszerna, że wymaga co najmniej opracowania książkowego.

Celem niniejszego opracowania w zamyśle autora jest pobudzenie czytelnika do rozpoczęcia własnego procesu myślowego w tej materii. Założeniem artykułu jest przegląd stron www wybranych przedsiębiorstw z listy diamentów Forbesa i stwierdzenie czy na w/w stronach znajduje się opis misji i wizji przedsiębiorstwa, a co za tym następuje stwierdzenie faktu czy takie komponenty znajdują się na witrynach internetowych badanych przedsiębiorstw.

\section{MISJA ORAZ WIZJA W FIRMIE}

Przedsiębiorstwo zaspokaja, przede wszystkim, potrzeby swoich właścicieli (właściciela), zarządu (menedżerowie), pracowników firmy, odbiorców, oraz innych przedsiębiorstw i instytucji współpracujących z nim (dostawców, kooperantów, banków, instytutów, uczelni itp.). Jednostka, która podejmuje działalność gospodarczą w warunkach wolnego rynku, powinna określić swoje cele, środki i metody ich osiągnięcia. Fundament do rozpoczęcia jakichkolwiek działań biznesowych powinna stanowić wizja, którą można sformułować w kategoriach uzyskania wyznaczonych celów jako inspirującą koncepcję przyszłości przedsiębiorstwa, jej potencjału i wyobrażenie pożądanej przyszłości.

Wizja to dalekosiężna aspiracje lidera związane $\mathrm{z}$ przedsiębiorstwem. $\mathrm{W}$ drugim znaczeniu wizja jest koncepcją modelową przyszłej struktury organizacji, jej funkcjonowania i postulowanego rozwoju podmiotu, określonego przez aspirację i kreatywną wyobraźnię właściciela (kierownictwa, członków podmiotu) [Stabryła, 2005, s. 48]. Tworzenie wizji przedsiębiorstwa to znajdowanie wariantów mających na celu odkodowanie przyszłości (wychodzenie od przyszło- 
ści do teraźniejszości), które trzeba jednak sprowadzić do realnej rzeczywistości [Janasz, 2009, s. 84].

Kolejnym krokiem na ścieżce tworzenia podwalin działania przedsiębiorstwa jest sprecyzowanie misji przedsiębiorstwa, która wyrażając posłannictwo przedsiębiorstwa, definiuje cel, dla którego przedsiębiorstwo zostało powołane oraz określa rolę, jaką ono odgrywa w danym środowisku [Buczkowska, 2012, s. 7-8]. W naukach o zarządzaniu sformułowanie misji stanowi punkt wyjścia dla ustalenia celów działania przedsiębiorstwa, strategii i programów rynkowych ich realizacji. Deklaracje zawarte w misjach przedsiębiorstwa mogą być formułowane $\mathrm{w}$ wąskim lub szerokim zakresie oraz $\mathrm{w}$ różnym stopniu uwzględniać zmienność warunków otoczenia [Czubała, 2013, s. 7]. Misja przedsiębiorstwa powinna powstać w wyniku szczegółowej analizy otoczenia, w którym dany podmiot egzystuje i działa, przeglądu zasobów własnych zarówno pod kątem materialnym jak i intelektualnym oraz przy szczególnym rozpoznaniu i implementacji konceptu intelektualnego na którym przedsiębiorstwo opiera swoje działanie. Warto zwrócić na to uwagę, aby misja zawierała takie elementy jak obszar działalności, zakres produktowy oraz sposób osiągnięcia zakładanej pozycji na rynku konkurencyjnym. Misja przedsiębiorstwa powinna powstać po przeanalizowaniu jego możliwości oraz warunków panujących $\mathrm{w}$ otoczeniu, a także czynników na nie wpływających. Do czynników tych należy zaliczyć:

- zagrożenia i szanse w otoczeniu,

- wymagania akcjonariuszy zewnętrznych,

- zasoby wewnętrzne,

- kulturę organizacji.

Misja powinna umożliwić uzyskanie odpowiedzi na następujące pytania [Drucker, 1992, s. 30-40]:

- na jakim polu działamy?

- kim są nasi klienci?

- jakie wartości oferujemy naszym klientom?

- jakie są obecne perspektywy rozwoju naszego pola działania?

- jakie pola działania powinniśmy obrać na przyszłość?

Misja firmy nabiera strategicznego znaczenia, gdy [Obłój, 1998, s. 235]:

- wyznacza kierunek i dotyczy przyszłości;

- wyraża marzenia i wyzwania, które stają się udziałem pracowników;

- proces jej realizacji jest wiarygodny. 
Rysunek 1. Schemat - wizja, misja, cele.

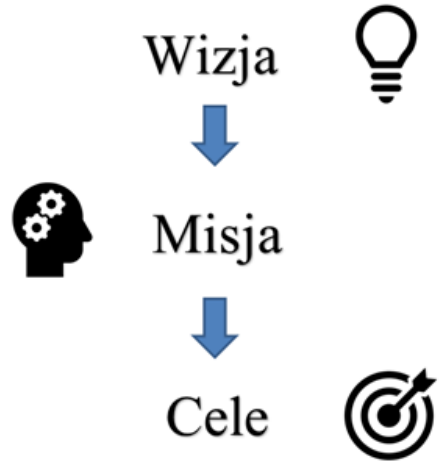

Źródło: opracowanie własne.

W 2007 roku po raz pierwszy w porozumieniu z redakcją miesięcznika „Forbes” firma dzisiaj nosząca nazwę Bisnode Polska opracowała zestawienie najbardziej dynamicznie rozwijających się firm w kraj, zwane potocznie „Diamentami Forbesa”. Rok 2017, jest czasem szczególnym, gdyż ranking „Diamentami Forbesa” obchodzi okrągłą 10 rocznicę jego polskiej premiery. W zestawieniu znalazły się firmy, które w trzech ostatnich latach najszybciej zwiększały swoją wartość. Brano pod uwagę firmy, które złożyły do KRS sprawozdanie finansowe za rok obrachunkowy lub opublikowały je w Monitorze Polskim B. Eliminowane są przedsiębiorstwa znajdujące się w upadłości lub likwidacji. Pozostały te o dodatnim wyniku finansowym i o współczynniku ryzyka niższym niż 4, ocenianym wg ratingu Bisnode.

Nagrodzone firmy dzielone są na trzy kategorie wg przychodów ze sprzedaży:

- firmy małe 5-50 mln zł;

- firmy średnie 50-250 mln zł;

- firmy duże powyżej $250 \mathrm{mln}$ zł. ${ }^{1}$

Wywiadownia Bisnode Polska zebrała dane o podmiotach gospodarczych, które złożyły w terminie raporty do Krajowego Rejestru Sądowego w 2015 roku. $\mathrm{Na}$ tej podstawie powstała baza blisko 3 tys. przedsiębiorstw, którym w tym roku wywiadownia przyznała pozytywny rating wiarygodności (na podstawie wskaźników EBIT i ROA). Wyłonione w rankingu przedsiębiorstwa mają wysoką płynność bieżącą i nie zalegają z płatnościami. Przedsiębiorstwa spełniające wszystkie te warunki musiały również wykazać się dodatnim wynikiem finansowym oraz wartością kapitałów własnych. ${ }^{2}$ 
Bisnode to firma zajmująca się dostarczaniem danych i analiz. Przedsiębiorstwo to działa w 18 krajach, a obecny stan zatrudnienia pracowników oscyluje w okolicach 2,5 tysiąca ludzi. Firma Bisnode zgodnie z informacjami ze strony internetowej oferuje inteligentne wykorzystanie danych. Oznacza to, że możemy połączyć, a następnie przeanalizować nasze dane, dane naszych klientów oraz te generowane każdego dnia na świecie zwanymi Big Data. ${ }^{3}$ Analitycy Bisnode Polska przygotowując najnowszą edycję rankingu Diamenty Forbesa wyceniali przedsiębiorstwa, stosując metodę szwajcarską, która łączy metodę majątkową oraz dochodową. Pierwsza nie wycenia potencjału pracowników i posiadanego know-how. Wycena na podstawie zysków nie uwzględnia z kolei wrażliwości na zmiany sezonowe lub koniunkturalne. Firmy, które dużo inwestują, mogą wykazywać niewielkie zyski. Połączenie tych obu metod rekompensuje te ułomności. Know-how, jeśli jest wartościowe, wpływa na zyskowność albo - w przypadku firm inwestujących - na wzrost majątku. Wartość przedsiębiorstw (W) jest średnią ważoną wartości ich majątku (Wm) i wartości dochodowej (Wd) według wzoru: śW $=(\mathrm{Wm}+2 \mathrm{Wd}) / 3$. Majątek wyceniono na podstawie średniej arytmetycznej jego wartości likwidacyjnej oraz wartości księgowej netto spółki, która kwotowo odpowiada kapitałowi własnemu firmy pomniejszonemu o wartości niematerialne i prawne. Wartość dochodowa to z kolei średnia zysków z lat 2013-2015. Wycena wartości nie uwzględnia wartości marek i dotyczy końca 2015 roku. $^{4}$

\section{CHARAKTERYSTYKA BADANIA NAUKOWEGO}

Do badania wybrany został najbardziej liczebny przedział rankingowy, czyli przedział firm małych, tj. mieszczących swoje przychody ze sprzedaży w przedziale 5 do 50 milionów. W obecnym rankingu Diamenty Forbesa 2017 segment ten zawiera 1606 przedsiębiorstw.

Celem badania było stwierdzenie czy obiekty badane umieszczają misję lub/oraz wizję przedsiębiorstwa na swojej stronie internetowej (o ile ją posiadają). Badanie częściowe jest typem badań statystycznych, w których charakterystyki statystycznego rozkładu w całej populacji dokonuje się, na podstawie wyników badań przeprowadzonych na podzbiorze populacji (próbce). Badanie, w którym wykorzystujemy metodę reprezentacyjną, w której próba dobierana jest losowo, wydaje się najbardziej odpowiednią metodą do tego typu badań. W celu uzyskania informacji na temat charakterystyki rozkładów statystycznych w ogólnej populacji, wybiera się losowo grupę osób, czyli próbę, na której można przeprowadzić badania mające na celu określenie odpowiednich rozkładów.

\footnotetext{
${ }^{3} \mathrm{http} / /$ www.bisnode.pl/o-nas-kontakt/o-bisnode/ [11.02.2017]

${ }^{4} \mathrm{http}: / /$ www.bisnode.pl/home/realizowane-rankingi/diamenty-forbesa/ [11.02.2017]
} 
Rysunek 2. Przykładowa część rankingu Diamenty Forbesa - przychody od 5 do 50 mln zł.

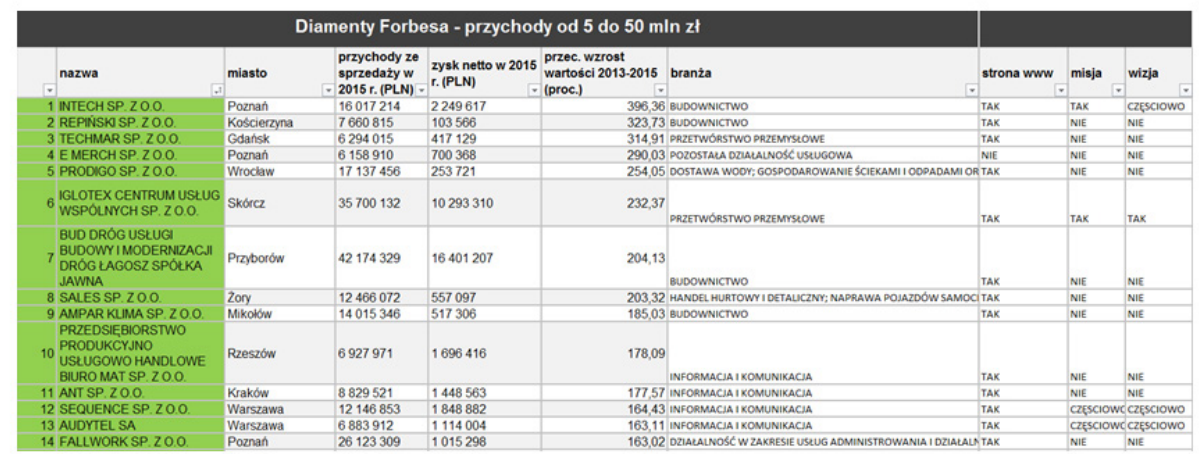

Źródło: opracowanie własne na podstawie www.diamenty.forbes.pl

Uzyskane wyniki są używane do charakterystyki całego zbioru, przy czym trzeba pamiętać, że wnioskowanie takowe jest obarczone błędem, którego wielkość możemy oszacować za pomocą rachunku prawdopodobieństwa. Ważnym aspektem sposobu jest wybór próbki. Ponieważ nie można wnioskować na podstawie całej populacji w ogóle, to chcemy, aby próba była dobrą reprezentacją całości. Najważniejszymi czynnikami wpływającymi na dokładność metody są: struktura zbiorowości, wykorzystany schemat losowania oraz liczebność próby. Istnieje możliwość wyznaczenia minimalnej liczebności próby w oparciu o określone parametry (m.in. dotyczące jakości wyników badania). Do tych parametrów należą:

- szacowana wielkość frakcji, czyli odsetek jednostek spełniających określoną cechę;

- maksymalny błąd oszacowania;

- poziom istotności, który interpretuje się jako prawdopodobieństwo, z jakim

popełniony zostanie błąd oszacowania o zadanej wartości maksymalnej;

- liczebność populacji generalnej (dla populacji skończonej). ${ }^{5}$

Minimalna wielkość próby określana jest różnie w zależności od tego, z jaką populacją mamy do czynienia czy mamy do czynienia (skończoną czy nieskończoną). W kwestii występowania danego rodzaju populacji to w praktyce rzadko spotykamy się z populacją nieskończoną, ale czasami badacze traktują populację skończoną jako populację o nieskończonej liczbie jednostek - szczególnie w przypadku bardzo dużej liczebności populacji). Dla populacji skończonej wzór na minimalną liczebność próby ma następującą postać: 


$$
N_{\min }=\frac{P(1-P)}{\frac{e^{2}}{Z^{2}}+\frac{P(1-P)}{N}},
$$

gdzie:

$\mathrm{P}$ - szacowana wielkość frakcji,

$\mathrm{z}$ - wartość wynikająca z przyjętego poziomu istotności $(\alpha)$, obliczana przy pomocy dystrybuanty rozkładu normalnego,

$\mathrm{N}$ - liczebność populacji generalnej (w przypadku populacji skończonej),

e - maksymalny błąd oszacowania. ${ }^{6}$

W celu oszacowania wielkości próby, dla podanego badania wykorzystano kalkulator wielkości próby dostępny w poniższej lokalizacji: http://www.statystyka.az.pl/dobor/kalkulator-wielkosci-proby.php. Wielkość próby dla populacji skończonej wynosi: 16

Rysunek 3. Wynik badania statystycznego.

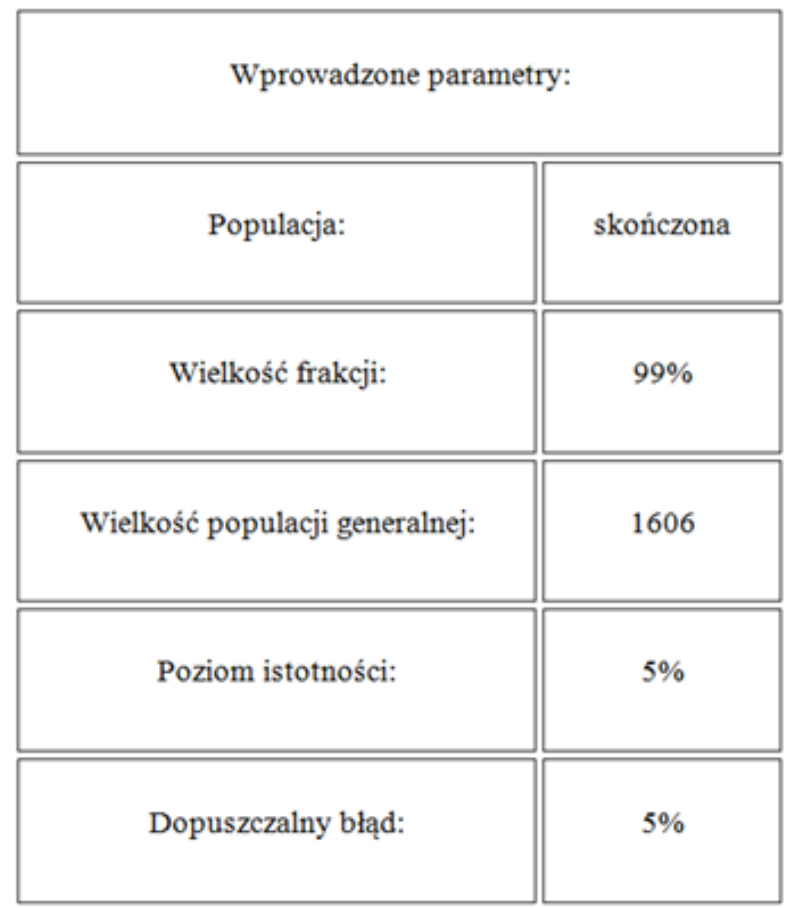

Źródło: opracowanie własne.

${ }^{6}$ http://www.statystyka.az.pl [11.02.2017] 
Do badania wybrany został najbardziej liczebny przedział rankingowy, czyli przedział firm małych, $\mathrm{tj}$. mieszczących swoje przychody ze sprzedaży w przedziale 5 do 50 milionów. W obecnym rankingu Diamenty Forbesa segment ten zawiera 1606 przedsiębiorstw. Autor badania zdecydował-się zbadać pierwsze 51 firm z rankingu oraz dodać do nich jeszcze 16 (zgodnie z wymogiem próby minimalnej) losowo wybranych firm. Dobór losowy został dokonany przy pomocy generatora losowań dostępnego na stronie www.losowe.pl.

Rysunek 4. Wynik losowania.

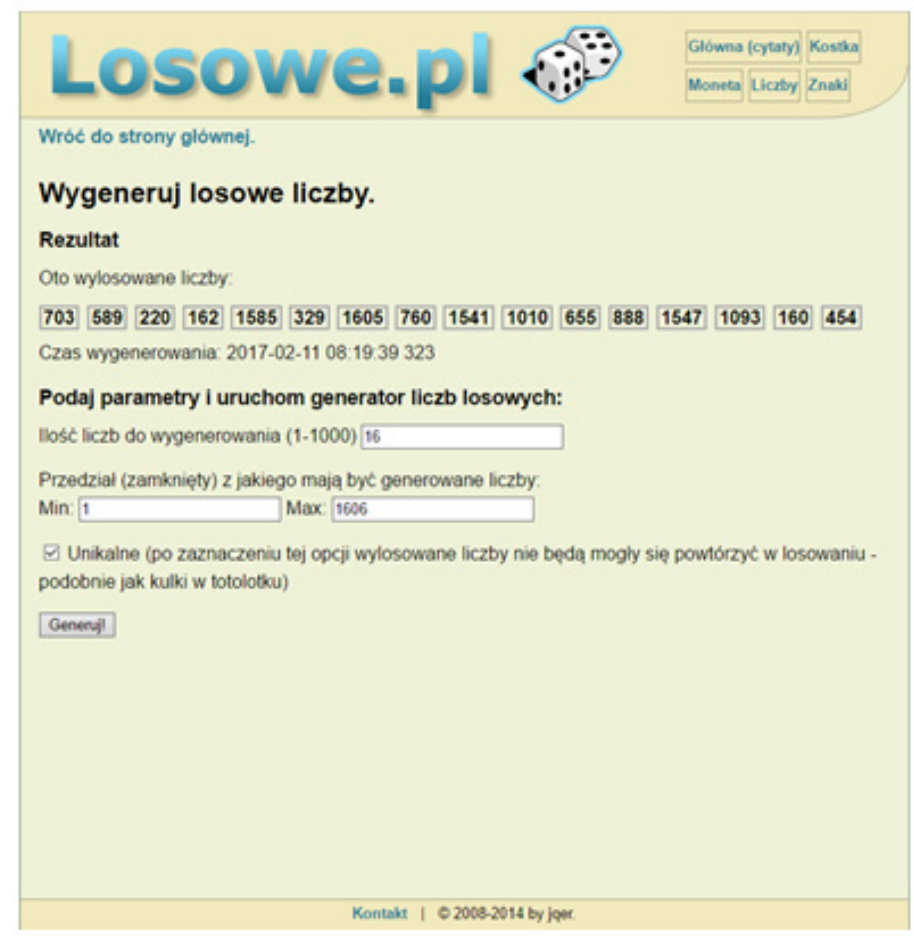

Źródło: opracowanie własne na podstawie www.losowe.pl

\section{WYNIKI BADAŃ}

Z wybranej grupy 67 firm, 3 firmy nie posiadały swojej strony internetowej, tak więc badaniu zostało poddanych 64 firmy. W arkuszu badawczym oprócz nazwy firmy oraz poziomu przychodów ze sprzedaży za 2015 umieszczona zostały rubryki określającej miasto, w którym przedsiębiorstwo ma główną siedzibę oraz zaczerpniętą z klasyfikacji PKD $2007^{7}$ nazwę sekcji, do której należy przedsiębiorstwo. Początkowo założeniem badania było powiązanie w/w zmien-

${ }^{7}$ http://stat.gov.pl/Klasyfikacje/doc/pkd_07/pkd_07.htm [21.03.2017] 
nych tj. miasto i sekcja z występowanie misji oraz wizji na stronie internetowej przedsiębiorstwa. W toku badania okazało się, że liczba firm posiadających misję oraz/lub wizję na swojej stronie internetowej jest taka mała, że poszukiwanie korelacji występowania w/w elementów z obranymi wcześniej zmiennymi jest bezzasadne. Autor badania zdecydował się na graficzne przedstawienie wyników badań obranej próby według poniższego podziału:

a) obecność samej misji na stronie internetowej,

b) obecność samej wizji na stronie internetowej,

c) obecność misji oraz wizji na stronie internetowej.

Wykres 1. Obecność misji na stronie www.

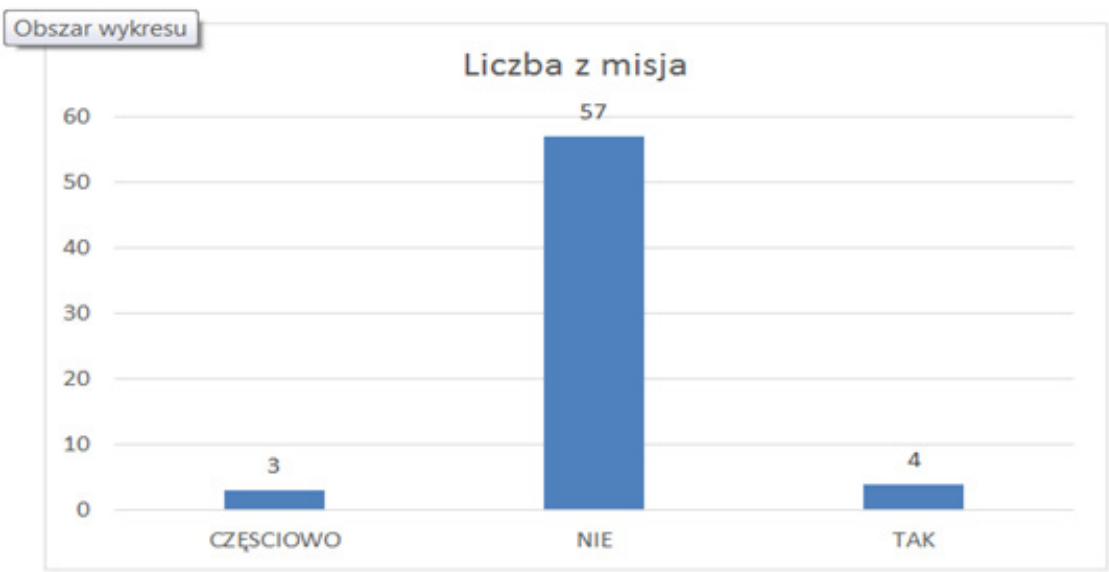

Źródło: opracowanie własne na podstawie przeprowadzonego badania.

Wykres 2. Obecność wizji na stronie www.

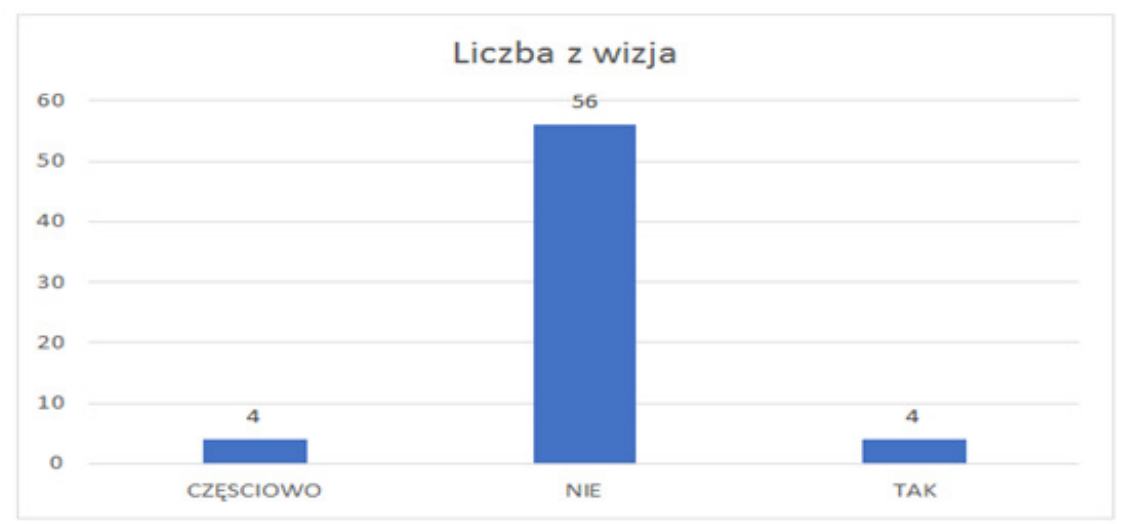

Źródło: opracowanie własne na podstawie przeprowadzonego badania. 
Wykres 3. Obecność wizji i misji na stronie www.

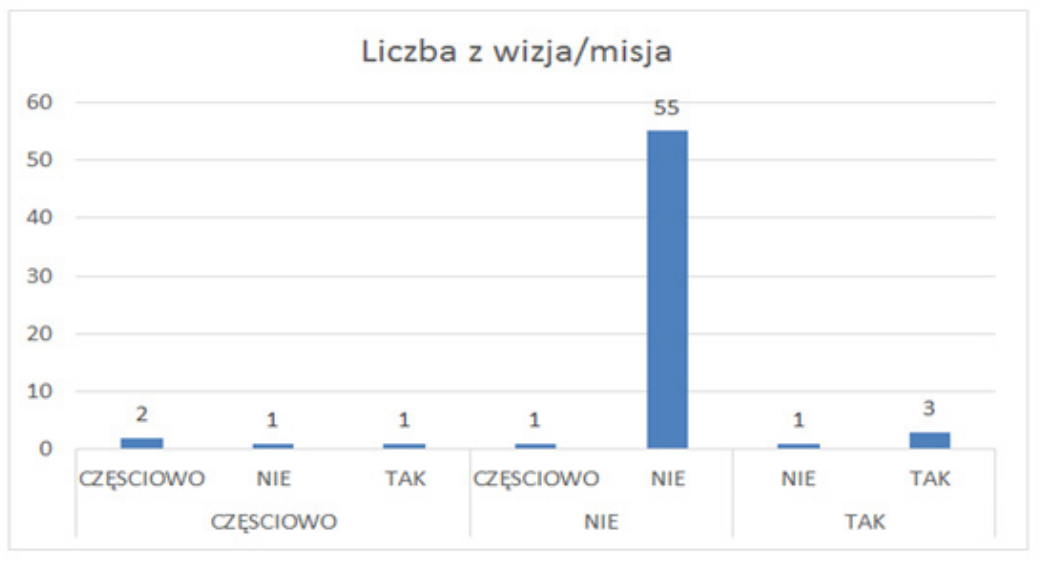

Źródło: opracowanie własne na podstawie przeprowadzonego badania.

Forma zaprezentowanych wykresów tj. wykresy słupkowe wskazują zdaniem autora w sposób najbardziej przejrzysty wyniki badań i obrazują częstotliwość występowania wizji oraz/lub misji na stronach internetowych wybranej próby przedsiębiorstw uwzględnionych w rankingu Diamenty Forbes 2016 przedział przychodów ze sprzedaży 5 do 50 milionów. Podsumowując prezentację graficzną, można stwierdzić, że powyższe wykresy $(1,2,3)$ dosyć wyraźnie wskazują, że umieszczanie misji oraz wizji firmy na stronie www przedsiębiorstwa nie jest praktyką powszechną wśród badanych jednostek.

\section{ZAKOŃCZENIE}

Założeniem artykułu był przegląd stron www wybranych przedsiębiorstw z listy diamentów Forbesa i stwierdzenie czy na w/w stronach znajduje się opis misji i wizji przedsiębiorstwa.

W wyniku badania stwierdzono, że publikowanie misji oraz wizji przedsiębiorstwa nie jest praktyką powszechną wśród badanych jednostek. Nie można tutaj jednoznacznie stwierdzić, czy badane firmy posiadają lub nie posiadają formalną lub nieformalną misję oraz/lub wizję oraz czy w przypadku posiadania powyższych elementów są one istotne dla funkcjonowania przedsiębiorstwa, a jedynie fakt, że misja oraz wizja nie są powszechnie umieszczane na stronie internetowej badanych przedsiębiorstw. Kolejnym krokiem, jaki należy wykonać w celu pogłębienia podjętego tematu, powinno być dokonanie pogłębionej analizy występowania misji oraz wizji w badanych podmiotów, formy jej ewentualnego występowania oraz istotności dla funkcjonowania badanych przedsiębiorstw. 


\title{
LITERATURA
}

Buczkowska A. (2012), Cele przedsiębiorstwa a pomiar jego dokonań, „Zeszyty Naukowe Uniwersytetu Szczecińskiego", nr 684.

Czubała A. (2013), Misje polskich eksporterów, „Marketing i Rynek”, nr 2.

Drucker P.F. (1992), Innowacje i przedsiębiorczość. Praktyka i zasady, PWE, Warszawa.

http://www.bisnode.pl [11.02.2017].

http://www.diamenty.forbes.pl [11.02.2017].

http://www.losowe.pl [11.02.2017].

http://stat.gov.pl [21.03.2017].

http://www.statystyka.az.pl_[11.02.2017].

Jagielski W. (2014), Misja jako cel kierunkowy przedsiębiorstw w branży piekarniczej „AUNC Zarządzanie” XLI, nr 2(2014).

Janasz W. (2009), Wizja strategiczna i misja w funkcjonowaniu przedsiębiorstwa, „Studia i Prace Wydziału Nauk Ekonomicznych i Zarządzania”, nr 12.

Obłój K. (1998), Strategia organizacji, PWE, Warszawa.

Stabryła A. (2005), Zarzadzanie w teorii i praktyce firmy, PWN, Warszawa-Kraków.

\section{PRESENCE OF THE MISSION AND VISION OF THE COMPANY ON THE WEBSITES OF THE SELECTED BUSINESS FROM FORBES 2017 DIAMOND RANKING}

\begin{abstract}
The vision and mission of the company is a competitive advantage that can not be easily copied. Maintaining a high degree of competitiveness in today's world requires, in addition to good business strategies, continuous innovation and flexibility, also the backbone of all activities and processes which constitutes a constitution of the company. The purpose of this article is to review the websites chosen by representative sample companies from the Forbes Diamonds list 2017 and to determine whether the above pages contain a description of the mission and/or vision of the company.
\end{abstract}

Keywords: mission, vision, Forbes, company 
